Saturday. January 1 st Eighteen hund ${ }^{d}$ forty two

I have on hand the following Stock this day. (viz)

One Span Canadian studs $\$ 150$. $\$ 150.00$

Two Devonshire cows $\$ 25$ ea Two Durham heifers (3 yr old) $\$ 25 \ldots . . .100 .00$

One Durham \& Ayrshire Bull $\$ 150$. One Steer Calf $\$ 5$. 155.00

Three South Down eyes $[s i c]$ \$25. ea. Two hf blood ewes $\$ 15$. One

lamb ewe $\$ 10$

Two South down Buck Lambs $\$ 10$ ea

20.00

One Two horse Lumber waggon $\$ 75$. One do $-\$ 20$.

95.00

“ Pleasure waggon $\$ 55$. Cart $\$ 15$. Sleigh $\$ 35$. 105.00

“Two horse plough \& Corn plough $\$ 10$. 1 pr Harrow $\$ 15$. 25.00

"Scythe \& Snathe 12/. 2 Hay forks 10\%. 2 dung forks 14/. 4.50

"Shovel \& Spade 14/. 2 axes 26/. Reel \& Line 8/. 3 Hoes 10/. Carpenters tools $\$ 15$. Lathe $\$ 8$. Curry Comb \&c 8/. Measures 6/.

Fanning Mill \$24. Corn Sheller \$10. Harness \$45.

Grindstone \$8. Post auger 12/. Rakes 8/. Wood Saw 8/.

2 Cattle chains $10 \% .2$ Baskets $6 /$. Cultivator $\$ 5$. Seed sower $\$ 5$.

2 Setts double harness $\$ 25$. 1 sett Single harness $\$ 15$.

1 Bush Scythe 10\%.

1 Hay Rake $\$ 6.1$ potato Hook 5/. 1 Cradle $\$ 4.00$

To us the important thing about the inventory is the total investment which it represents. Add the $\$ 973.50$ valuation of stock and equipment as of January 1,1841 , to the offer of $\$ 3,500$ for the farm on February 24,1841 , and the total is an investment of nearly $\$ 4,500$.

What was that $\$ 4,500$ worth in the way of income? On February 4, 1842, one Jacob Ross, records Bement, "offered me $\$ 225$ for my farm for one year with stock and implements which he is to pay in advance." That is about 5 per cent on Bement's investment without allowing for insurance on buildings, depreciation, and taxation. No conclusion, however, can be drawn about Bement's income from renting his farm because we do not know the details of his agreement with his tenant.

\title{
The Teaching of Business History
}

Two major universities in the United States have recently added to their curriculum work in business history. Last autumn on returning from the Army, the author of the article on business history at Stanford University in the present issue of the Bulletin was appointed Assistant Professor of Business History in the 
Graduate School of Business. Professor Coman will give two courses, one course in general business history and one in the business history of the Pacific Coast. Dr. Richard C. Overton, who has been appointed to the faculty of Northwestern University, last autumn introduced a course in business history in the School of Commerce of the University. Thus the subject of business history is gaining increasing recognition as a field for study in American universities.

\section{Questions and Answers in Business History}

Who was the first American business man?

We could make a strong claim for Thomas Studley, chief merchant of the Virginia Company in Jamestown, Va., 1607.

Has Business ever had a patron saint?

The Roman god Mercury came close to it, in so far as he protected foreign commerce and local retail trade. Thieves as well as business men, however, came to look to him as a patron. St. Nicholas was the patron of traveling merchants and sailors, but he was too generous to yield profits.

Who is responsible for the switch of the foreman class from management to labor?

Chiefly the industrial capitalists of the early part of this century who took away many of the foreman's functions instead of elucating him to do a better job. A good example of a bad policy, deliberately and blindly pursued. To be sure, there were excuses and provocations.

What was the philosophy of business men in the nineteenth century?

Primarily the production of goods or services at ever lowering costs so as to compete with other concerns for a market. What workers might lose in money wages, they would gain from lower prices. 